\title{
ビデオシンポジウム 気管食道再建術
}

特別発言

日野原正

日本気管食道科学会は, 昭和 24 年設立以来, 気道・食道領域の疾患を扱う学会として発展し てきたが, 本シンポジウムで呼吸器外科ならび に消化器外科汸ける最新の知見と手術手技を visibleに見せて戴いたことは極めて有意義で あり，本学会が意図する学際的な目的が余すと ころなく開陳された点，高く評価したい。

気管・食道再建術は，まず広範な病変部を切 除して根治的治癒を図ることを第一目的とし， かつ患者 QOL の観点から機能の温存を図るこ とをその理念とすることに異論はない。

1. 根治手術後, 久損部再建㵴器として 2 つ の方法がある。

1) 自力 (自前) 法：自家組織（藏器）によ る修復（組織欠損に伴う機能損失あり）。

2 ) 他力 (出前) 法：同種, 異種臓器による
修復（拒否反応。臓器移植による倫理問題 あり）と人工資材による修復。

上記の中で人工資材による方法が可能ならば 問題がないが，気管・食道は外界に晒される管 腔でかつ可動する臓器なので, 将来ともその開 発には隘路がある。

2. 機能の温存については, 患者からみた満 足度を重視すべきは論を俟たない。

下表は現在思索中の「頭頸部癌患者の QOL スコアー」表であるが，呼吸と嚥下機能は生存 に必須であり，ことに気管内誤嚥患者の苦痛は 相当なるを知る要がある。

また，音声機能は快適なる人間的生活を保証 するものであり，嗅覚，味覚はしばしば等閑視 されるが，この領域でも耳鼻咽喉科医の果たし うる役目は大と考える。

頭頸部癌患者の QOL スコアー（試案）

\begin{tabular}{|c|c|c|c|c|c|c|}
\hline & & 1 & 2 & 3 & 4 & 5 \\
\hline 生 & 呼吸機能 & 良い & 大体良い & 普通 & やや悪い & 悪い \\
\hline 存 & 嶼下機能 & 普通食 & 全 粥 & 5 分䉼 & 流動食 & 経管食 \\
\hline 生 & 言語機能 & 普通に話せる & ゆっくり話せる & $\begin{array}{l}\text { 食道発声 } \\
\text { 人工喉頭 }\end{array}$ & 全く話せない & \\
\hline $\begin{array}{l}\text { 活 } \\
\text { レ }\end{array}$ & 運動機能 & 普通に動く & $\begin{array}{l}\text { 肩がある程度し } \\
\text { か上がらない }\end{array}$ & $\begin{array}{l}\text { 手で物がつか } \\
\text { めない }\end{array}$ & $\begin{array}{l}\text { 両上肢の機能 } \\
\text { 障害 }\end{array}$ & \\
\hline ベ & 浴 & 普通にできる & 一部介助がいる & 介助が必要 & できない & \\
\hline ル & 眠 & 正 常 & やや不眠気味 & 大変不眠 & 眠剤必要 & \\
\hline 付 & 喀痰喀出機能 & 良 好 & やや悪い & 大変悪い & & \\
\hline 常 & 覚 & 良 好 & やや悪い & 大変悪い & & \\
\hline 項 & 味賞 & 良好 & やや悪い & 大変悪い & & \\
\hline
\end{tabular}

獨協医科大学気管食道科 